\title{
Assessment of Sustainable Sediment Management Strategies using RESCON 2 Model: A Case Study of Budhi Gandaki Hydroelectric Project
}

\author{
Sujata Adhikari, Umesh Singh, Ishwar Joshi, Bhola Nath Ghimire
}

\begin{abstract}
Reservoir sedimentation is one of the main challenges faced by storage hydroelectric projects all over the world. Particularly for a country like Nepal which lies in the center of "Himalaya Arc", a region with one of the highest sediment yields in the world, reservoir sedimentation can be one of the biggest issues for storage type projects. It may result in the loss of huge capital investment and revenues. Thus to minimize the reservoir sedimentation problem and to ensure the sustainability of the existing as well as upcoming future storage projects, timely measures for sediment management strategy are required. RESCON 2 model sponsored by Word Bank is the tool for the rapid assessment of sustainable sediment management strategies. The model is based on the Life Cycle Management approach which focuses on managing the reservoir by economical and technical evaluation of different sediment management alternatives to extend the life of the reservoir for an almost indefinite lifetime. Thus this study is carried out for the assessment of sustainable sediment management technique for proposed Budhi Gandaki Hydroelectric project (BGHEP) using the RESCON 2 model. One of the important parameters for the assessment of sustainable sediment strategies is specific sediment yield. So in this study 9 sediment management techniques incorporated in RESCON 2 model have been evaluated based on two specific sediment yield, 1) estimated from BQART empirical method, 2) data from the BGHEP study report. From the calculation it was found that the BQART model overestimated the sediment yield than presented in BGHEP report and the result indicated Sluicing as the best sediment management technique for both the cases having the highest Aggregate net present value. From sensitivity analysis, Aggregate Net present value and reservoir capacity were found sensitive to unit benefit of reservoir yield, coefficient of variation and annual runoff.
\end{abstract}

Index Terms - BudhiGandaki Reservoir, Life cycle management approach, RESCON 2 model, Reservoir Sedimentation.

\section{INTRODUCTION}

Nepal boasts one of the highest per capita hydropower potential in the world [1]. However, lack of hydropower development has lead the country into a chronic power shortage in the past decade. The current electricity demand of the country is $20.251 \mathrm{GWh}$ which is $16 \%$ higher than the generation (17.421 GWh). Almost all of the operating

Sujata Adhikari, Department of Civil Engineering, Pulchowk Campus, Nepal.

Umesh Singh, Senior Researcher Hydrolab Pvt. Ltd, Lalitpur, Nepal.

Bhola nath Ghimire, Department of Civil Engineering, Pulchowk Campus, Nepal.

Ishwar Joshi, Hydrolab Pvt. Ltd, Lalitpur, Nepal. hydropower plants are of RoR or PRoR type, which can only operate at full capacity during high flow season. So, the demand-supply gap increases during the dry season due to significant drop in power production.

To cater the current and the future electricity demands, the Government of Nepal has now put forward an ambitious hydropower development plan of generating 10,000 MW by year 2026. This hydropower development plan strategy has prioritized development of storage reservoir type projects in order to have sufficient power production throughout the year and in the future, for managing the seasonal generation deficit.

In line with the nation-wide storage hydroelectric development of GON to cater future electricity demand, a number of project has been identified and studied. Budhi Gandaki Hydroelectric project (BGHEP) is one of them. Budhi Gandaki Hydroelectric project (BGHEP) is a 1200 MW storage project located on the Budhi Gandaki River, approximately $2 \mathrm{~km}$ from its confluence with Trishuli River at Benighat. The project will generate $4250 \mathrm{GWh}$ of electricity annually with a guaranteed generation capacity within the range of $970-1200 \mathrm{MW}$. So, BGHEP project is expected to significantly contribute towards balancing the supply and demand of the electricity during the dry season.

The main purpose of the project is to store water during monsoon season and use it for electricity generation during the dry season. Sediment transported by the flow will also be trapped in the reservoir, reducing the reservoir storage capacity and particularly, for storage type projects, the reservoir sedimentation is one of the major issues affecting reservoir storage capacity more rapidly than the initial estimation [2]. Therefore in order to minimize the impact from reservoir sedimentation and to increase reservoir life proper sediment management strategies are required. So, a reservoir sedimentation management studies will have a key role in the sustainability of BGHEP reservoir.

\section{PROBLEM DEFINITION}

There were more than 45000 large dams built all around the world, in the 20th century, for several purposes such as power generation, flood control, domestic or industrial water supply [3]. Most of these dams have traditionally been designed under the "design life" paradigm. The design life approach requires estimation of the reservoir sedimentation rate and trap efficiency and a sediment storage pool volume, called dead storage, equivalent to the design life (typically 50 or 100 years) is provided. As a result, every year $0.5-1.0 \%$ of the world's reservoir capacity is lost due to sedimentation

Tarbela Dam, which was constructed in 1968 AD under 


\section{Assessment of Sustainable Sediment Management Strategies using RESCON 2 Model: A Case Study of BudhiGandaki Hydroelectric Project}

the design life, faced the sedimentation problem since commissioning. The dead storage of the reservoir was completely filled up and the live storage of the reservoir decreased from 11.939 billion cubic meters in 1974 to 8.550 billion cubic meters in 2006, a reduction of $28.28 \%$ [4]. The Welbedacht Reservoir in South Africa lost $86 \%$ of its original storage volume between 1973 and 2005 [5]. In the case of Nepal, Kulekhani (90MW), the only storage project (capacity $8.53 \mathrm{Mm}^{3}$ ) has been reported that the project has lost more than $25 \%$ of its capacity in a period of 20 years [6].

As from the above study, the design life approach, although feasible for most conventional civil infrastructure, is generally seems to be ineffective while designing sustainable dams and their reservoirs. Under this paradigm, consequences beyond the design life are not addressed, leading to abandoning or decommissioning of the reservoirs. So, to prevent such a scenario, it requires to shift from conventional design life approach to alternative approach where reservoir are managed so that there potential will be fully utilize for long period as possible. The alternative approach to design life is life cycle management approach [7]. Life-cycle management approach allows sediment management technology to be considered in new dam designs from the very start. Applying the same concept to existing dams and reservoirs requires refurbishment to allow for reservoir sediment management to promote sustainable development. A major difference between the life-cycle management approach and the design life approach is the focus on preventing storage loss caused by reservoir sedimentation. The life-cycle management approach eliminates the threat of losing the reservoir's ability to store water over the very long term and promotes the continued use of the dam and reservoir, providing utility to both current and future generations. Thus, it seems that in many countries as well as in Nepal sedimentation problem appears to have emerged due to lack of proper regulation and sediment management strategies in regulated rivers and reservoirs. Thus to preserve and restore storage capacity, both for existing and future reservoirs, "mitigation measures are urgently needed" [8]. At the same time, [7] proposed a reservoir life-cycle management strategy, which emphasized the concepts of economic evaluation and sustainable development of sediment management, putting forward the concepts of intergeneration equity and conceptual model-RESCON based on principles of sustainable development [9].

So, this paper studies the applicability of RESCON 2 Model for assessment of sediment management strategies for the case study of Nepal .

\section{OBJECTIVES}

1. To apply RESCON 2 model for the assessment of sustainable sediment management strategy for Budhi Gandaki reservoir.

2. To conduct sensitivity analysis of various parameters in the RESCON 2 model

\section{RESCON 2 MODEL}

RESCON model is based on the computer program, which is sponsored by World Bank in 1999. It was designed for pre-feasibility studies to rank the economic performance of a sediment management techniques. The data input, reading of results are performed through a Graphical User Interface (GUI) and the calculation is done in Excel. The key algorithm of RESCON is based on economic optimization for determining the most viable solution which is supported by technical evaluation of basic parameters [10].

The RESCON is based on the "Life Cycle Management Approach". The first version of RESCON includes five sediment management strategies that are: Flushing, Hydrosuction-sediment removal system (HSRS), Trucking, and Dredging along with No Action option. With the advancement of technology and a greater understanding of sedimentation characteristics, in 2017 the World Bank upgraded it to RESCON 2 [10]. RESCON 2 version consists of nine sediment management techniques in which Catchment management, Sluicing, Density Current Venting, and By-Pass are additional to previous version. Along with the addition of new sediment management techniques, RESCON 2 also upgraded its economic analysis and added additional features to access the climate change effect [10].

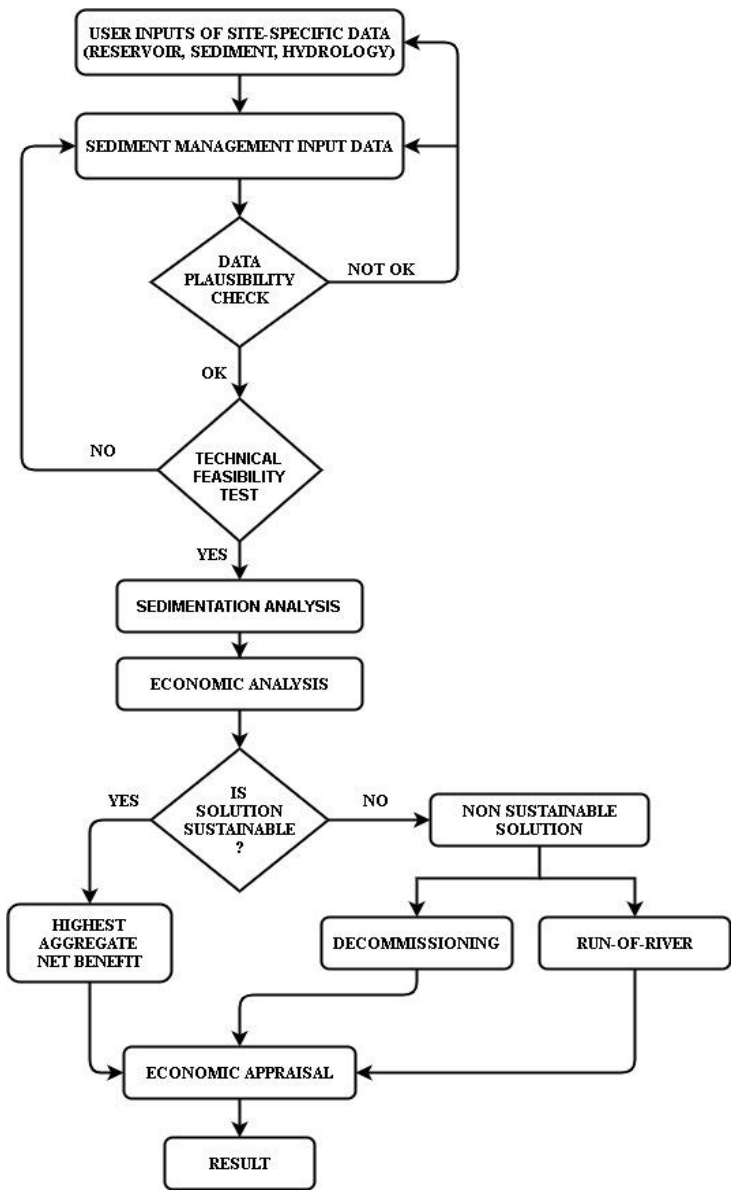

Fig 1: Flowchart for RESCON 2 Model

\section{A. Structure of RESCON 2 Model}

The main aim of RESCON 2 model is to select the viable sediment management technique which is technically feasible and having the maximum Net Economic benefit. The main steps involved in the model are shown in the flow chart in Figure 1. 


\section{B. Sediment Management Techniques adopted in RESCON 2 Model}

The various sediment management technique adopted in RESCON 2 are:

\section{No Action}

2. Catchment Management

3. Removal of Deposits

a. Flushing

b. Dredging

c. Hydrosuction Sediment Removal System (HSRS)

d. Trucking

4. Sediment Routing

a. Sediment By-pass

b. Sluicing

c. Density Current Venting

\section{Economic optimization in RESCON 2}

The main principle of RESCON 2 model is based on economic optimization where aggregate net present value (NPV) is maximized within the reservoir lifetime. The optimization function utilizes the algorithm which is supported by engineering relationships. The following relation is used for economic optimization.

Maximize $\sum_{\mathrm{t}=\mathrm{D}}^{\tau} N B_{\mathrm{t}} \cdot d^{\mathrm{t}}-C 2+\boldsymbol{V} \cdot \mathrm{d}^{\tau}$
Subject to: $S_{\mathrm{t}+1}=S_{\mathrm{t}}-M+X_{\mathrm{t}}$

$\mathrm{NBt}=$ annual net benefits in year $\mathrm{t}$,

$\mathrm{d}=$ discount factor (defined as $1 /(1+\mathrm{r}$ ), where $\mathrm{r}$ is rate of discount),

$\mathrm{C} 2=$ initial cost of construction for proposed dam $(=0$ for existing dam),

$\mathrm{V}=$ salvage value,

$\mathrm{T}=$ terminal year,

$\mathrm{St}=$ remaining reservoir capacity in year $\mathrm{t}$,

$\mathrm{M}=$ trapped annual incoming sediment,

$\mathrm{Xt}=$ sediment removed in year $\mathrm{t}$,

From the above optimization equation, the best sediment management technique having the highest benefit will be choosen. The Net benefit calculation is different for different sediment management techniques.

\section{Assessment of Reservoir Sediment Managment strategies in Budhi Gandaki Hydroelectirc Project}

Budhi Gandaki Hydroelectric project (BGHEP) is a 1200 MW storage project located on the Budhi Gandaki River, approximately $2 \mathrm{~km}$ from its confluence with Trishuli River at Benighat as shown in the Figure 2. The project has been listed as the National Pride Projects by the Government of Nepal. The project consists of $263 \mathrm{~m}$ high concrete double curvature arc dam built to create a reservoir of $4467 \mathrm{Mm}^{3}$ volume for the seasonal regulation of flow. $2226 \mathrm{Mm}^{3}$ of the reservoir will serve as the active live storage and the 708 $\mathrm{Mm}^{3}$ will serve as the dead storage. The project

will generate $4250 \mathrm{GWh}$ of electricity annually with a guaranteed generation capacity within the range $970-1200$ MW. So, BGHEP project is expected to significantly contribute towards balancing the supply and demand of the electricity during the dry season.

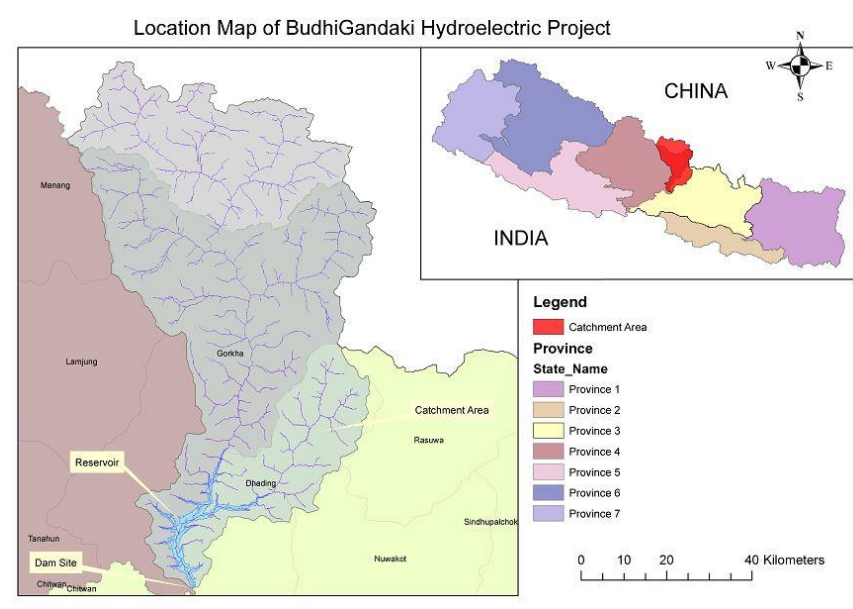

Fig 2: Location of Budhi Gandaki Hydroelectric Project

\section{E. sediment yield estimation study}

The amount of sediment reaching or passing a point of interest in a given period is called Sediment yield. It refers to the amount of sediment exported by a basin over a period, which is also the amount that will enter a reservoir located at the downstream [4]. For reservoir sedimentation, estimation of the sediment yield from catchments and the amount of sediments transported by rivers are very important. For BudhiGandaki Project, two sediment yield estimation are used in RESCON 2 model for analysis. They are:

1. Sediment yield estimation carried out by BudhiGandaki Hydroelectric authority.

2. Sediment yield estimation using inbuilt BQART empirical Model.

Based on the BGHEP report, Bedload in BudhiGandaki River can be expected to fall in the range of $10 \%$ to $35 \%$ of the suspended load. Bedload was considered $30 \%$ of suspended load, then the mean annual total sediment load is found to be in the order of $10.5 \pm 3$ million tonnes/year.

Sediment Yield using BQART model : RESCON 2 has an inbuilt tool to estimate sediment yield using BQART in the case of sediment measurement that is not available. BQART uses catchment properties, basin temperature, lithology, and land use properties for quick assessment of sediment yield as presented in Table 1. The expression for predicting sediment yield is as follows:

$Q s= \begin{cases}\omega B Q^{0.31} A^{0.5} R T, & \text { for } T>2^{\circ} \mathrm{C} \\ 2 \omega B Q^{0.31} A^{0.5} R T, & \text { for } T<2^{\circ} \mathrm{C}\end{cases}$

Table 1: Sediment Yield calculation using BQART

\begin{tabular}{|l|l|}
\hline Description & Value \\
\hline Drainage Area $\left[\mathrm{km}^{2}\right]$ & 5,005 \\
\hline $\begin{array}{l}\text { Maximum Basin Relief } \\
{[\mathrm{km}]}\end{array}$ & 8 \\
\hline $\begin{array}{l}\text { Average Basin Temperature } \\
{\left[{ }^{\circ} \mathrm{C}\right]}\end{array}$ & 25 \\
\hline $\begin{array}{l}\text { Basin averaged lithology } \\
\text { class }\end{array}$ & $\begin{array}{l}\text { Sedimentary rocks, } \\
\text { unconsolidated sedimentary } \\
\text { cover, alluvial deposits }\end{array}$ \\
\hline $\begin{array}{l}\text { Ice cover as percentage of } \\
\text { total drainage area }(\%)\end{array}$ & $25 \%$ \\
\hline Basin Trap Efficiency (\%) & $75 \%$ \\
\hline $\begin{array}{l}\text { Basin human-influenced } \\
\text { soil erosion class }\end{array}$ & $\begin{array}{l}\text { Mixture of the competing } \\
\text { influences of soil erosion and } \\
\text { conservation }\end{array}$ \\
\hline
\end{tabular}


Assessment of Sustainable Sediment Management Strategies using RESCON 2 Model: A Case Study of BudhiGandaki Hydroelectric Project

\begin{tabular}{|l|l|}
\hline $\begin{array}{l}\text { Mean annual total } \\
\text { sediment inflow mass } \\
\text { (mill.tons/year) }\end{array}$ & 25.3 million tonnes/a \\
\hline
\end{tabular}

\section{F. Input data preparation}

Input data that are required to run the RESCON 2 model are tabulated below:

Table 2: BudhiGandaki Reservoir Geometry input for RESCON 2.

\begin{tabular}{|l|l|l|}
\hline Description & Value & Unit \\
\hline $\begin{array}{l}\text { Original gross storage } \\
\text { capacity of the reservoir }\end{array}$ & $4,467,000,000$ & {$\left[\mathrm{~m}^{3}\right]$} \\
\hline $\begin{array}{l}\text { Original inactive storage } \\
\text { capacity of the reservoir }\end{array}$ & $1,290,000,000$ & {$\left[\mathrm{~m}^{3}\right]$} \\
\hline $\begin{array}{l}\text { Existing gross storage } \\
\text { capacity of the reservoir }\end{array}$ & 0 & {$\left[\mathrm{~m}^{3}\right]$} \\
\hline $\begin{array}{l}\text { Existing active storage of } \\
\text { the reservoir }\end{array}$ & 0 & {$\left[\mathrm{~m}^{3}\right]$} \\
\hline $\begin{array}{l}\text { Existing inactive storage } \\
\text { of the reservoir }\end{array}$ & 0 & {$\left[\mathrm{~m}^{3}\right]$} \\
\hline $\begin{array}{l}\text { Representative river bed } \\
\text { width at the envisaged } \\
\text { dam location }\end{array}$ & 80 & {$[\mathrm{~m}]$} \\
\hline $\begin{array}{l}\text { Maximum pool elevation } \\
\text { of reservoir }\end{array}$ & 540 & {$[\mathrm{masl}]$} \\
\hline
\end{tabular}

Table 3: BudhiGandaki Reservoir Hydrological data input for RESCON 2

\begin{tabular}{|l|l|l|}
\hline Description & Value & Unit \\
\hline $\begin{array}{l}\text { Mean annual reservoir } \\
\text { Water inflow }\end{array}$ & 7,010 & $\begin{array}{l}{[\mathrm{million}} \\
\left.\mathrm{m}^{3} / \mathrm{a}\right]\end{array}$ \\
\hline $\begin{array}{l}\text { Coefficient of variation of annual } \\
\text { run-off volume }\end{array}$ & 0.1 & {$[-]$} \\
\hline $\begin{array}{l}\text { Representative water } \\
\text { temperature in the reservoir }\end{array}$ & 25 & {$\left[{ }^{\circ} \mathrm{C}\right]$} \\
\hline Intra-annual Variation of water & & \\
\hline Probability of Exceedance(\%) & $\%$ of MAR & \\
\hline $15 \%$ & $72 \%$ & \\
\hline $30 \%$ & $35 \%$ & \\
\hline $60 \%$ & $13 \%$ & \\
\hline
\end{tabular}

Table 4: BudhiGandaki Reservoir sediment input for RESCON 2

\begin{tabular}{|l|l|l|}
\hline $\begin{array}{l}\text { Specific weight of in-situ } \\
\text { reservoir sediment (bulk density) }\end{array}$ & 1.41 & {$\left[\right.$ tonnes $\left./ \mathrm{m}^{3}\right]$} \\
\hline $\begin{array}{l}\text { Mean annual total (suspended and } \\
\text { bedload) sediment inflow mass }\end{array}$ & 13.5 & $\begin{array}{l}\text { [million } \\
\text { tonnes/a] }\end{array}$ \\
\hline$\%$ bedload of total sediment inflow & 0.23 & {$[\%]$} \\
\hline Duration of bedload transport & 0.17 & {$[\%]$} \\
\hline Intrannual Variation of water & & \\
\hline Probability of Exceedance (\%) & $\%$ of MAS & \\
\hline $15 \%$ & 0.65 & \\
\hline $30 \%$ & 0.091 & \\
\hline $60 \%$ & 0.007 & \\
\hline
\end{tabular}

Table 5: Economic Analysis parameters for BudhiGandaki Reservoir.

\begin{tabular}{|l|l|l|}
\hline Description & Value & Unit \\
\hline $\begin{array}{l}\text { Unit cost of construction } \\
\text { Per } \mathrm{m}^{3} \text { of reservoir }\end{array}$ & 0.58 & {$\left[\$ / \mathrm{m}^{3}\right]$} \\
\hline
\end{tabular}

\begin{tabular}{|l|l|l|}
\hline capacity & 2593000000 & {$[\$]$} \\
\hline $\begin{array}{l}\text { Total cost of reservoir } \\
\text { impoundment }\end{array}$ & 0.1 & {$[\%]$} \\
\hline Discount rate & 0.12 & {$[\%]$} \\
\hline $\begin{array}{l}\text { Market interest rate of } \\
\text { annual retirement fund }\end{array}$ & 0.050358 & {$\left[\$ / \mathrm{m}^{3}\right]$} \\
\hline $\begin{array}{l}\text { Unit benefit of reservoir } \\
\text { yield }\end{array}$ & 907550000 & {$[\$]$} \\
\hline Decommissioning cost & 0.9 & {$[\%]$} \\
\hline $\begin{array}{l}\text { Capacity loss for } \\
\text { Characterization of a } \\
\text { reservoir as non } \\
\text { sustainable }\end{array}$ & 25930000 & {$[\$ / \mathrm{a}]$} \\
\hline $\begin{array}{l}\text { Total annual operation \& } \\
\text { maintenance costs }\end{array}$ & & \\
\hline
\end{tabular}

\section{G. Evaluation of RESCON 2 Result}

Based on the data provided on the Table 2, 3, 4 and 5, RESCON 2 model was run for base case scenario (no action condition) to determine the storage loss. According to the sediment yield estimation, two cases were considered. They are;

case (a) having sediment yield as presented in BGHEP report (13.5MT/year) and another case (b) having sediment yield estimated by BQART (25.3MT/year). According to the result of RESCON 2 model, for case(a) the Gross storage loss of reservoir after 50 years was $10.44 \%$ and active storage loss was $13.7 \%$ and for 100 years gross storage loss was $20.88 \%$ and active storage loss was $26 \%$. Whereas for case(b), the Gross storage loss after 50 years was $19.51 \%$ and active storage loss was $23.80 \%$ and for 100 years gross storage loss was $37.64 \%$ and active storage loss was $40.12 \%$. Then each technically feasible sediment management strategies were evaluated in RESCON 2 model under these two cases.

\section{Evaluation of Catchment Management Results:}

The result of Catchment Management shows that the implementation of catchment management is feasible and reservoir sustainability was achieved leading the reservoir life more than 300 years. For case (a) the self optimization from RESCON model was initiated to determine the optimum implementation strategy which gave the implementation year of 66 years with Aggregate NPV 765.723 mill. USD and reservoir storage at the end of 300 year was 2417.728 mill. $\mathrm{m}^{3}$.

For case (b) the optimum implementation strategy which gave the implementation year of 27 years with Aggregate NPV 763.275 mill. USD and reservoir storage at the end of 300 year was 927.992 mill. $\mathrm{m}^{3}$.

\section{Evaluation of Flushing Results:}

The optimize result from the model shows that for both the cases flushing is technically feasible and sustainable because the flushing sustain the reservoir storage above the storage threshold for more than 300 years. The result of flushing strategies is optimized in two stages, non-sustainable and sustainable stage separated by Long term Capacity(LTC).For case (a) the major flushing feasibility criteria SBR is 9.5 which is greater than 1 and LTCR is 0.33 . The result shows single flushing event at year 169 during non-sustainable stage is able to sustain the reservoir gross storage over 300 years. The gross storage capacity after 300 year was 1720.653 mill. 
$\mathrm{m}^{3}$ and aggregate net present value for first 300 year is 765.706 mill. USD.

For case (b) the major flushing feasibility criteria, SBR is 5.1 which is greater than 1 and LTCR is 0.33 . The result shows optimum time for implementation of flushing in non-sustainable stage is 169 years while the frequency of flushing during sustainable stage is 5 years. The long term gross capacity sustain by flushing is 1442.752 mill. $\mathrm{m}^{3}$ and aggregate net present value is 763.051 mill. USD.

To evaluate the efficiency of flushing, one of the critical measure is water surface elevation during flushing (ELf). In BGHP, the normal water surface elevation is $540 \mathrm{~m}$ and ultimate minimum operation level is $467 \mathrm{~m}$. Thus it may not be possible for reservoir to draw down during flushing. So during such case pressure flushing may prevail. To investigate how the water surface elevation effect the flushing solution, various possible draw down water surface elevation were analyzed in RESCON model to calculate SBR and LTCR value. Figure 3 shows the result of this analysis.

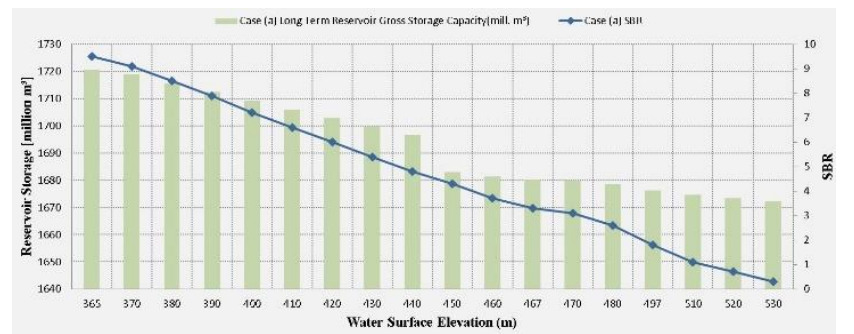

Figure 3: Long Term Reservoir storage and SBR at different water elevation.

The figure shows that when the water surface elevation is gradually increased SBR value goes on decreasing which causes the efficiency of flushing to decrease as the result, long terms reservoir gross storage that was available as got significantly decreased. This shows flushing efficiency parameter varied directly with the level of reservoir drawdown during flushing. So achieve maximum flushing efficiency reservoir need to drawdown to full extent. If drawdown is not possible then flushing can be carried out with decreased flushing efficiency.

\section{Evaluation of Dredging Results:}

In case (a), result shows implementation year is 281 years and frequency of dredging is every 1 year. At this condition aggregate NPV obtained is 765.709 mill. USD and long term gross capacity is maintained at 1853.823 mill. $\mathrm{m}^{3}$.

For case (b), optimize solution was obtained when implementation year was 193 and frequency of dredging operation was 41 years. Aggregate NPV obtained was 763.013 mill. USD and the long term reservoir storage was maintained at 1393.316 mill. $\mathrm{m}^{3}$. However, maximum amount of sediment to be removed per dredge event was found to be $690.247 \mathrm{mill} . \mathrm{m}^{3}$ which is not possible as sediment volume removed by typical system for one year is $11 \mathrm{mill} . \mathrm{m} 3$ (RESCON manual). So by considering 10 mill. $\mathrm{m}^{3}$ dredging amount, manual implementation routine was carried out to sustain the reservoir. After some trial reservoir was able to sustain for 300 year when dredging is installed in 50 year and frequency of dredging is every 2 year. The aggregate NPV obtained was 752.764 mill. USD and reservoir storage available after 300 year was 702.223 mill. $\mathrm{m}^{3}$.

\section{Evaluation of Trucking Results:}

Trucking is technically feasible but the practical assessment of the trucking depends upon the possibility of complete drawdown of the reservoir and whether the volume of deposited sediment calculated by RESCON model can be removed. Economic optimization routine was performed for cases (a) and (b). For case (a) optimum years for implementation is 297 year with frequency of 10 years in second phase with the maximum sediment removed of 0.2 mill. $\mathrm{m}^{3}$ per trucking event.

For case (b). RESCON determines the optimum year for implementation is 193 year and frequency of trucking is 42 years.Result shows the trucking implementation schedule where trucking requires to remove 707.315 mill. $\mathrm{m}^{3}$ of deposited sediment, which is not practically possible to attain during on year of trucking event. Thus for BGHEP, trucking is considered not practically possible.

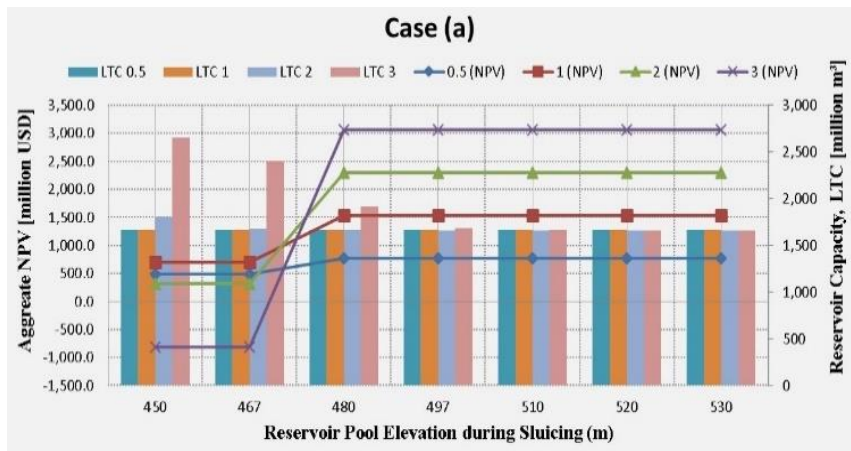

Figure 4: Evaluation of sluicing operation for case (a)

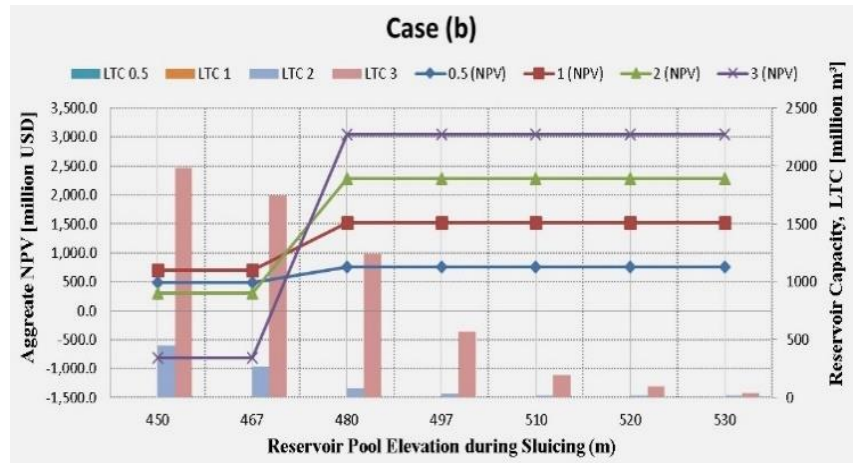

Figure 5: Evaluation of sluicing operation for case (b)

\section{Evaluation of Sluicing Results:}

For case (a) the optimize results shows the the first year for implementation of sluicing is 25 year and last until the reservoir life ends. The optimum duration of sluicing is 3.5 months each year after the implementation. Aggregate Net present value for first 300 years of operation is 765.757 mill. USD while long term reservoir gross storage after 300 year is 1737.305 mill. $\mathrm{m}^{3}$. Similarly for case (b) the optimize results shows the the first year for implementation of sluicing is 17 year and last until the reservoir life ends. The optimum duration of sluicing is 3.5 months each year after the implementation. Aggregate Net present value for first 300 years of operation is 763.430 mill. USD while long term reservoir gross storage after 300 year is 1241.097 mill. $\mathrm{m}^{3}$. sluicing efficiency is analyzed by varying the water surface elevation for different duration of operation (month) for both case (a) and case (b) as shown in figure 4 and figure 5. 


\section{Assessment of Sustainable Sediment Management Strategies using RESCON 2 Model: A Case Study of BudhiGandaki Hydroelectric Project}

\section{Evaluation of By-pass Results:}

For the case (a) the optimization framework determined 297 year as the implementation year and 0.5 month as the duration of by-pass operation which led to the reservoir sustainability. The aggregate net present value for first 300 year was 765.709 mill. USD and gross storage maintained at the end of the 300 year was 1674.785 mill. $\mathrm{m}^{3}$.

For case (b), optimization framework of RESCON model couldn't determine the optimum solution to sustain the reservoir, hence considered non sustainable. So attempt was made to last the reservoir gross storage till 300 years. After few trial, reservoir life was able exceed 300 years by implementing first by-pass at 50 years and duration of by-pass operation at 1.5 month each year. Reservoir storage capacity after 300 year was $490.143 \mathrm{mill} \mathrm{m}^{3}$ and aggregate Net present value of 300 year of application was 742.293 mill. USD.

\section{H. Sensitivity Analysis}

In-order to determine the sensitive parameters and their effect over the assessment of sediment management technique sensitivity analysis for various parameters were carried out. Figure 6 represent change of Aggregate NPV due to variation in $\mathrm{Cv}$, there is decrease in NPV with increase in $\mathrm{Cv}$. Figure 7 represent the unit benefit of reservoir yield versus aggregate NPV which shows below $0.05 \mathrm{~m}^{3}$ all the sediment management technique are not economical as the Aggregate NPV drps below zero. Figure 8 shows the Mean Annual inflow versus Aggregate NPV which indicates that increase in Mean annual inflow, increases the Aggregate NPV. Figure 9 shows the comparison of different sediment management techniques under two cases:

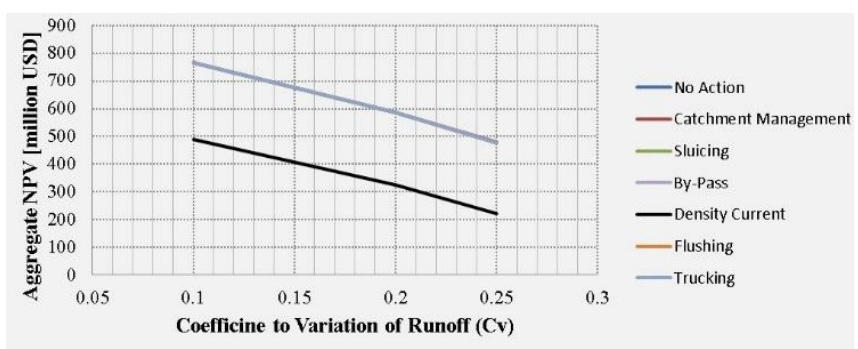

Figure 6: Evaluation of Cv and Aggregate NPV

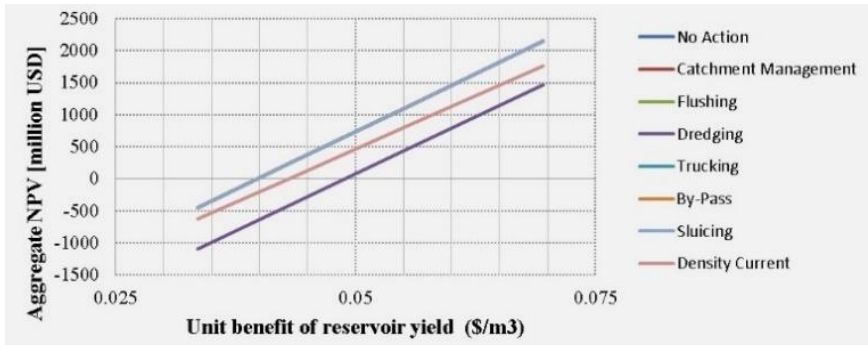

Figure 7: Evaluation of Unit benefit of Reservoir yield and Aggregate NPV

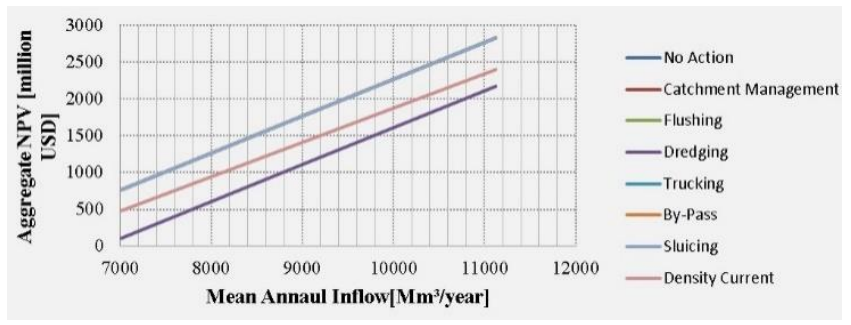

Figure 8: Evaluation of Mean Annual Inflow and Aggregate NPV

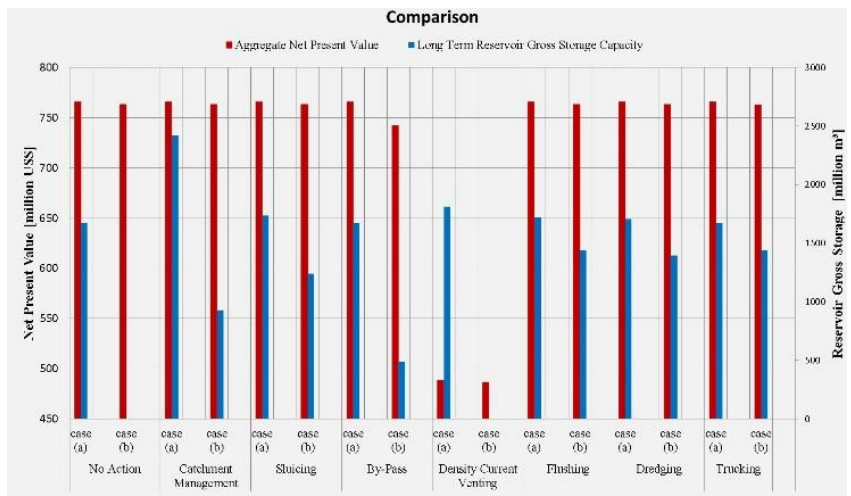

Figure 9: Comparison of different sediment management techniques.

\section{DISCUSSION AND CONCLUSION}

The Sediment yield from the catchment to the reservoir is the important parameter which greatly influences the determination of sustainable solution. Figure 9 shows that for both the cases of sediment yield Sluicing is found to be the best sustainable sediment management strategy. In case (a), Sluicing has the highest aggregate NPV of 765.757 mill. USD and in case (b) sluicing have the highest aggregate NPV of 763.43 mill. USD. Thus it shows that the implementation of sluicing in BGHEP is the best sediment management solution even in the case of higher sediment yield than the estimate in the BGHEP report.

Similarly from the sensitivity analysis, efficiency of flushing is highly sensitive to the water elevation during flushing as the value of SBR decreases with the increase in water surface elevation.

Thus this shows flushing is effective when reservoir water elevation is drawn down. Also in the case of Sluicing, reservoir pool elevation and duration of operation also has significant effect in the aggregate NPV. So optimum water elevation need to be determined for generating highest benefit from the strategy. Likewise from the sensitivity analysis, Coefficient of Variation, Unit benefit of reservoir yield and mean annual inflow to the reservoir has significant impact on aggregate NPV. So these critical parameter needs to be determine effectively when analyzing the sediment management technique. Thus this shows that RESCON 2 model can be very appropriate when determining the sustainable sediment management technique during the initial phase of the project. However the inbuilt BQART model has over-estimated the sediment yield for BGHEP, so for project with no sediment yield data, careful judgment is required when using BQART equation while running RESCON 2 model.

\section{RECOMMENDATION}

RESCON 2 is still in the phase of development, so there are many improvements to be made for better results. As for sustainability, RESCON 2 model is analyzed upto 300 years, so for long term analysis it would be more realistic if return period flood event are incorporated in the reservoir storage development and also expected trend of change in sediment yield is incorporated in the model analysis. 


\section{REFERENCES}

[1] O. A. C. Hoes, L. J. J. Meijer, R. J. Van Der Ent and N. C. Van De Giesen, "Systematic high-resolution assessment of global hydropower potential," PloS one, vol. 12, p. e0171844, 2017.

[2] S. Giri, "Reservoir Sedimentation as a 'Chunk'of Dam Health: A Glimpse of Real-World Practices and the State-of-the-Art Approaches," in Proceedings of First National Dam Safety Conference, 2015.

[3] W. C. on Dams, Dams and development: A new framework for decision-making: The report of the world commission on dams, Earthscan, 2000.

[4] G. L. Morris and J. Fan, Reservoir sedimentation handbook: design and management of dams, reservoirs, and watersheds for sustainable use, McGraw Hill Professional, 1998.

[5] R. Huffaker and R. Hotchkiss, "Economic dynamics of reservoir sedimentation management: optimal control with singularly perturbed equations of motion," Journal of Economic Dynamics and Control, vol. 30, p. 2553-2575, 2006.

[6] D. P. Sangroula, "Sediment Management for Sustainability of Storage Projects in Himalayas-A case study of the Kulekhani Reservoir in Nepal," in International Conference on Small Hydropower-Hydro Sri Lanka, 2007.

[7] A. Palmieri, F. Shah, G. Annandale and A. Dinar, "Reservoir conservation volume I: the RESCON approach," Washington, DC: World Bank, 2003.

[8] A. J. Schleiss, M. J. Franca, C. Juez and G. De Cesare, "Reservoir sedimentation," Journal of Hydraulic Research, vol. 54, p. 595-614, 2016.

[9] H. Yuan, Q. Shi, L. Xiaoying, X. Jinming, L. Dan and Z. Hui, "Sediment management decision making of the Sanmenxia reservoir based on RESCON model," African Journal of Agricultural Research, vol. 10, p. 2332-2443, 2015.

[10] P. E. Nikolaos, S. Palt, G. W. Annandale and P. Karki, "Reservoir Conservation Model Rescon 2 Beta," World Bank, International Bank for Reconstruction and Development, Washington, DC, 2017. 